\title{
EFFECT OF COUNTRY OF ORIGIN EMPLOYEE, WORK DISCIPLINE AND JOB SATISFACTION ON EMPLOYEE PERFORMANCE IN MCCONNELL DOWELL COMPANY SERVICE BATAM INDONESIA
}

\author{
Ade Nasution Parlaungan ${ }^{1}$, Denny Ammari Ramadhan ${ }^{2}$ \\ ${ }^{1}$ Sekolah Tinggi Ilmu Ekonomi Labuhan Batu, Indonesia, \\ adenasution@gmail.com \\ ${ }^{2}$ Management, Universitas Gadjah Mada, Indonesia, \\ dennyammary15@gmail.com
}

\begin{abstract}
Origin country individual employees and significant positive effect on employee performance, with at value of 3,112 and 0,002 significant value. With significantly limit $<0.05$, then Ho is rejected Ha accepted.

Labor discipline individually no relation to the performance of employees. With $t$ for 0864 and the significant value was 0.390. With significantly limit $<0.05$, then $\mathrm{Ho}$ is accepted Ha rejected.

Individual job satisfaction does not affect the performance of employees. With $t$ count equal to 0.228 and 0.820 significant value. With significantly limit $<0.05$, then $\mathrm{Ho}$ is accepted Ha rejected. From the results of an analysis that adjusted $R 2$ of 0.090 , this means that $9.0 \%$ of dependent variables influenced by independent variables consisting of variable employee national origin, work discipline, job satisfaction.

Country of origin of employees, work discipline, job satisfaction simultaneously (together) effect on the performance of employees of a company McConnell Dowell Services Batam. Based on the results of the regression test is known that the normally distributed variables.
\end{abstract}

Key Word: Job Satisfaction, Employee Performance, Home state employees, WorkDiscipline

\section{Background}

Batam is known as one of the industrial city, which consists of many companies with this type of work is different. One example of a company that engaged in the fabrication company. McConnell Dowell Services (Batam), having Tanjung Uncang, Batam. This company is a company engaged in the fabrication of steel construction, mechanical works, piping, module and rack assembly, the concrete structure. 
Each company has a different problem that must be faced, one of the problems is an employee. Employees are the human resources in the company to be managed professionally in order to create a balance between the needs of employees with the demands and capabilities of the company's organization. According to Hasibuan (2011), the role of humans is always active and dominant in every activity of the organization because people become planners, perpetrators, and determines the realization of organizational goals.

The company's goal is not possible without the active participation of employees in spite of tools owned by the company so sophisticated. The active role of employees needed to maximize the work so that the processing time according to predetermined targets, with the active participation of employees this will contribute significantly to the company to improve performance. A company will continue to grow if the management of human resources is well managed and continued survival is always affected by various factors related to staffing issues.

Management is a process to achieve the purpose of the organization or company. Management could have as a collection of logical and systematic knowledge as well as personal creativity, along with skills. Management wants to achieve organizational goals efficiently and effectively.

\section{Literature Review}

\section{Country of Origin}

At companies that go international, there are activities Human Resource Management changed. According to Morgan (in Justine and Purwanto, 2009), International Human Resource Management can be described in three dimensions:

1. Activities Human Resources which broadly includes procurement of labor, allocation, and utilization.

2. Category of the countries involved in the activities of the International Human Resources Management:

a. the host country, where a branch may be placed 
b. country of origin, where the company has its headquarters in

c. other countries that may be a source of labor, capital, and other inputs.

3. Three categories of employees in multinational companies:
a. employees of the host country
b. employees of the country of origin
c. The third state employees

According to Dowling (in Justine and Purwanto, 2009), complexity Human Resource Management International can be attributed to six factors:

1. More Activities Human Resources

2. The need for a Broader Perspective

3. More involvement in Employees Personal Life

4. Changes in emphasis between the Task Forces Mixed As Expats and Local Employees

\section{Work Discipline}

According to Hasibuan (2011), discipline is awareness and willingness to comply with all company rules and social norms in force. Discipline is the sixth operative functions of human resource management. The better the discipline of employees, the higher the performance of employees.

\section{Job satisfaction}

According to Hasibuan (2011) job satisfaction is an emotional attitude of fun and loved his work. This attitude is reflected by morale, discipline, and work performance. Job satisfaction in work enjoys job satisfaction in the work by gaining praise the work, placement, treatment, equipment, and the atmosphere of a good working environment. Job satisfaction outside of work is employee satisfaction is enjoyed outside of work with the amount of remuneration to be received from their work, so that he can buy needs - needs. 


\section{Employee performance}

\section{Employee Performance}

According to Irham Fahmi (2011), the performance is the result obtained by a good organization that is profit-oriented organizations and non-profit oriented that produced over a period of time. According to Indra Bastian (in Irham Fahmi, 2011), the performance is an overview of the level of achievement of the implementation of an activity /program /policy in realizing the goals, objectives, mission. and vision of the organization as stated in

\section{Framework}

The framework in this study are as follows:

Figure 1 Framework

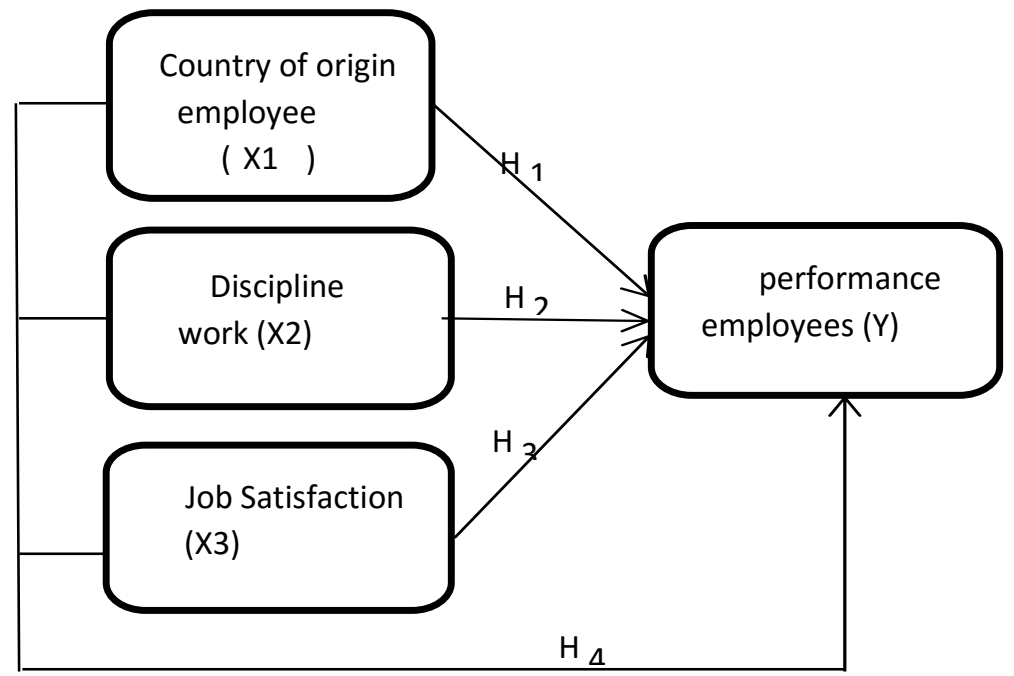

\section{RESEARCH METHODS}

\section{Population}

According to Sugiyono, (2012), the population is generalization region consisting of objects or subjects that have certain qualities and characteristics defined by the researchers to learn and then be deduced. The population in this study are employees at McConnell Dowell Services totaling 257 people. 


\section{Samples}

According to Sugiyono (2012), the sample is part of the number and characteristics possessed by this population. Samples were taken from the population using the formula Slovin amounting to as much as 100 People

\section{RESULTS AND DISCUSSION}

\section{Respondents age}

Data of respondents by age of respondent can be seen in the table below.

Figure 2. Age Of The Respondent

\begin{tabular}{|c|c|c|}
\hline Age & Number Of Respondents & Percentage \\
\hline$\leq 20$ years & 7 & $7 \%$ \\
\hline $21-30$ years & 41 & $41 \%$ \\
\hline $31-40$ years & 35 & $35 \%$ \\
\hline $41-50$ years & 12 & $12 \%$ \\
\hline$\geq 51$ years & 5 & $5 \%$ \\
\hline TOTAL & 100 & $100 \%$ \\
\hline
\end{tabular}

Source: Primary Data processing (2018)

Based on data from the Figure above, it can be seen that the majority of workers aged between 21-30 years as many as 41 people or $41 \%$, were aged 20 years and $7 \%, 35 \%$ were aged $31-40$, aged $41-50$ years $12 \%$, and the aged $\geq 51$ years $5 \%$.

\section{Education Respondents}

Figure 3. Education Respondents

\begin{tabular}{|l|l|l|}
\hline Education & Respondents & Percentage $(\%)$ \\
\hline High School & 78 & $78 \%$ \\
\hline Diploma & 8 & $8 \%$ \\
\hline Degree & 14 & $14 \%$ \\
\hline TOTAL & 100 & $100 \%$ \\
\hline
\end{tabular}

Source: Primary Data processing (2018)

Based on the presentation of the above table can be seen that the majority of workers are high school education as much as 78 or $78 \%$. It shows that the characteristics of 
the job is the need to employ the production section. This shows that the higher the education level, the better the quality of the employee.

\section{Respondents by Gender}

Figure 4. Respondents by Gender

\begin{tabular}{|c|c|c|}
\hline Gender & Total & Percentage \\
\hline Man & 85 & $85 \%$ \\
\hline woman & 15 & $15 \%$ \\
\hline Total & 100 & $100 \%$ \\
\hline
\end{tabular}

Sources: Primary data is processed (2018)

Based on data from the above table, it can be seen that the majority of workers are male as many as 85 people or $85 \%$. While women as much as 15 or $15 \%$. This type of work at the company is a fabrication which requires more physical exertion of men than women physical exertion.

\section{Respondents by Country of Origin}

Figure 5. Respondents by Country of Origin Table Employees

\begin{tabular}{|l|l|l|}
\hline Country Of Origin & Total & Percentage \\
\hline Netherlands & 5 & $5 \%$ \\
\hline America & 3 & $3 \%$ \\
\hline Singapore & 2 & $2 \%$ \\
\hline Australia & 2 & $2 \%$ \\
\hline India & 2 & $2 \%$ \\
\hline Indonesia & 86 & $86 \%$ \\
\hline Total & 100 & $100 \%$ \\
\hline
\end{tabular}

Source: Primary Data Processed (2018)

Based on the above table can dilhat that the majority of workers are from Indonesia with 86 people (86\%). It shows that the McConnell Dowell Company provide employment opportunities for local people. 


\section{Respondents Based Work Period}

Figure 6. Respondents Based Work Period

\begin{tabular}{|l|l|l|}
\hline Years Of Service & Total & Percentage \\
\hline 3 months & 36 & $36 \%$ \\
\hline 6 months & 45 & $45 \%$ \\
\hline 1 year & 8 & $8 \%$ \\
\hline 2 years & 6 & $6 \%$ \\
\hline 3 years & 5 & $5 \%$ \\
\hline Total & 100 & $100 \%$ \\
\hline
\end{tabular}

Source: The Primary Data Processed (2018)

Based on the above table shows that the highest job is 6 months with the number of 45 people (45\%) and 3 months 36 (36\%), 1 in 8 people (8\%), 2 years 6 people (6\%), and 3 -year 5 people (5\%). This indicates that the length of work it will affect the performance of employees.

\section{Research result}

\section{Test Instruments Data}

Figure 7. Test Reliability instrument

\begin{tabular}{|c|c|c|c|c|}
\hline No. & Variables & Item & Cronbach Alpha & Information \\
\hline 1 & Country of origin & 15 & .609 & reliable \\
\hline 2 & Discipline & 15 & .684 & reliable \\
\hline 3 & Job satisfaction & 15 & 0.648 & reliable \\
\hline 4 & Performance & 15 & .620 & reliable \\
\hline
\end{tabular}

Source: Primary Data processing (2018)

Based on the above table shows that the results of tests carried out on the whole is unreliable. The results can be seen in Table Cronbach Alpha where values above 0.6 , which means that variable is reliable. 


\section{Classic assumption test}

Normality Test Result Data

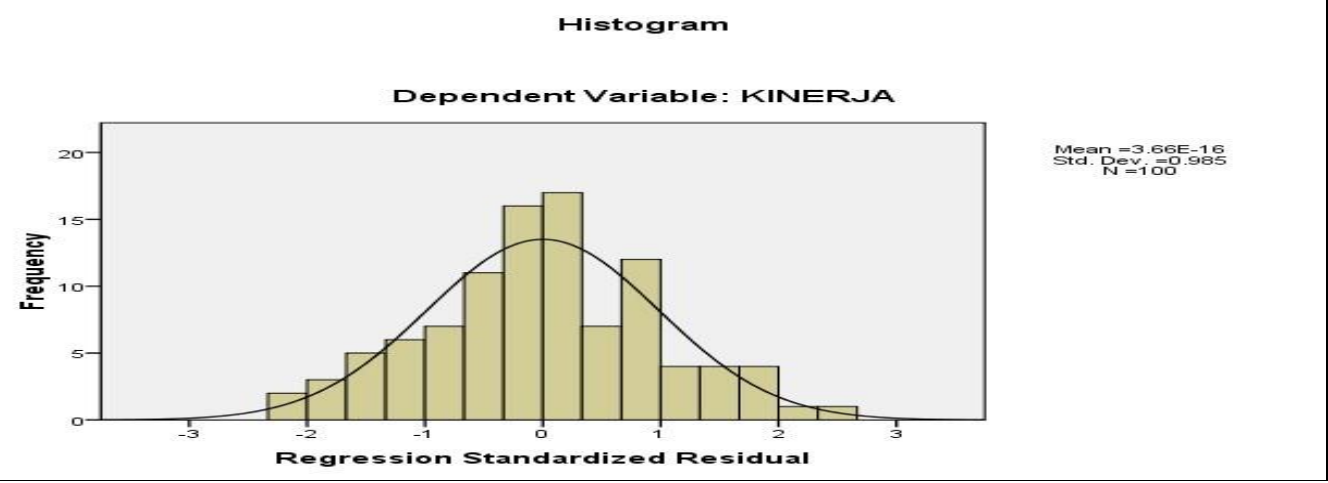

Source: SPSS output Enclosure

Based on the results of the normality test above shows that the bell-shaped curve, which means downloading test results are normally distributed.

Normality Test Results data in this study can be seen in the histogram above with regard dots P-Normal Regression Standardized Residual Plots of the dependent variable.

Histograms Normality Test Data

Normal P.P Plot of Regression Standardized Residual

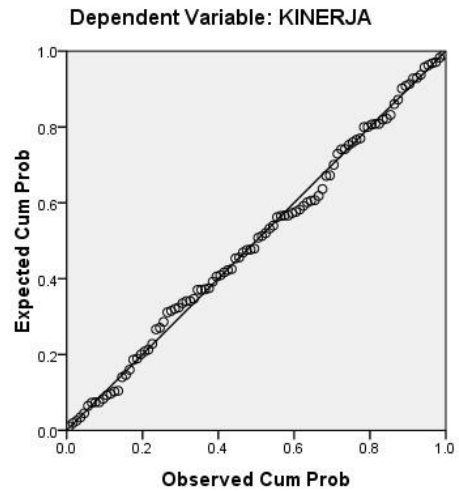


In the picture above it is clear that the data is normally distributed, where the points are located around the diagonal line create a point in the same direction.

\section{Test Results Multicollinearity}

Test Results Table Multicollinearity

\begin{tabular}{|c|l|c|c|l|}
\hline \multirow{2}{*}{ No. } & \multirow{2}{*}{ variables } & \multicolumn{2}{|c|}{ Colinearity statistic } & \multirow{2}{*}{ Information } \\
\cline { 3 - 4 } & & tolerance & VIF & \\
\hline 1 & $\begin{array}{l}\text { Country of Origin } \\
\text { employees }\end{array}$ & .942 & 1,061 & Non Multicolinieritas \\
\hline 2 & Discipline & 0.888 & 1,127 & Non Multicolinieritas \\
\hline 3 & Job satisfaction & 0.901 & 1,110 & Non Multicolinieritas \\
\hline
\end{tabular}

\section{Test Heteroskidastity}

Test Results image Heteroskidastity

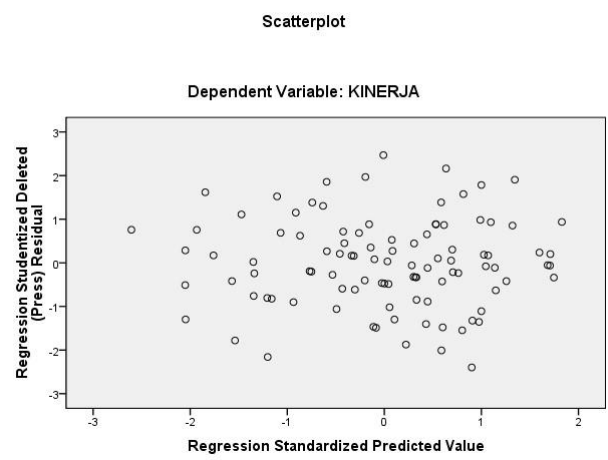

Source: Annex output SPPS 16.0

The graph above shows that the dots spread randomly, and does not form a specific pattern clearly, this means that no irregularities in this study. 


\section{Test Instruments}

\section{T- test}

\section{a. Originally Variable State Employees $(X 1)$}

Based on $\mathrm{t}$-test criteria are then obtained $\mathrm{t}$ count $>\mathrm{t}$ table $(3,112>1,985) \mathrm{H} 0$ rejected $\mathrm{H} 1$ accepted and can be concluded that there is a significant positive effect between countries of origin employees $(X 1)$ on employee performance $(\mathrm{Y})$.

\section{b. Variable Work Discipline $(X 2)$}

For $\mathrm{t}$-test is required to determine $\mathrm{t}$ and $\mathrm{t}$ table based on output $\mathrm{t}$ are 0.864 and $\mathrm{t}$ table is based on statistics table at a significance level of $0.05 / 2$ with $\mathrm{df}=\mathrm{nk}$ 1 or $100-4-1=95$. The results obtained for $t$ table is $1.985 \mathrm{t}$-test with the following

Based on t-test criteria are then obtained $t<t$ table $(0.864<1.985)$, then Ho is rejected and $\mathrm{Ha}$ is received it can be concluded that there is no significant positive influence between work discipline $(X 2)$ on employee performance $(Y)$.

\section{c. Variables Job Satisfaction $(X 3)$}

For t-test is required to determine $\mathrm{t}$ and $\mathrm{t}$ table based on output $\mathrm{t}$ are 0.228 and $\mathrm{t}$ table is based on statistics table at a significance level of $0.05 / 2$ with $\mathrm{df}=\mathrm{nk}-$ 1 or $100-4-1=95$.

Based on $t$-test criteria are then obtained $t<t$ table $(0.228<1.985)$, then Ho is accepted and $\mathrm{Ha}$ is received it can be concluded that there is no positive effect between job satisfaction $(X 3)$ on employee performance $(Y)$.

\section{Test F}

Based on the above statement obtained F count $>F$ table $(4,270>2,70)$ with a significant level $(0.007<0.05)$, then Ho is rejected Ha is received so that it can be said that the country of origin of employees $(X 1)$, work discipline $(X 2)$ and job satisfaction (X3 ) simultaneously (together) have a significant effect on employee performance $(\mathrm{Y})$ 


\section{Coefficient of Determination}

Results of the coefficient of determination

From the test results table or R2 R Square shows the coefficient of determination. From the test results obtained determination coefficient R2 value of 0343 or $34.3 \%$. While the value of R Square is 0,118 or $11.8 \%$ It showed about $11.8 \%$ variable employee performance $(\mathrm{Y})$ can be explained by the country of origin of employees $(X 1)$, work discipline $(X 2)$, and job satisfaction $(X 3)$. Or practically can be said that the contribution of the effect of national origin of employees $(X 1)$, work discipline $(X 2)$, and job satisfaction $(X 3)$ to variable employee performance (Y) was $11.8 \%$ and the remaining $88.2 \%$ is influenced by other variables not studied.

\section{Discussion}

\section{Country of Origin Influence Employees on Employee Performance}

Based on the research that has been described statistically by using SPSS 16 it can be seen that the country of origin of the employees have $t(3,112>1.985)$ with significance t table $(0.002<0.05)$, then Ho is rejected and Ha accepted so that it can be concluded that country of origin is partially employee has a positive and significant influence on employee performance.

\section{Work Discipline Against influence the performance of employees.}

Based on the research that has been described statistically by using SPSS 16 it can be seen that the work discipline has $t$ count equal to $(0.864<1.985)$ with significance t table $(0.390>0.05)$, then Ho is accepted and $\mathrm{Ha}$ is rejected so that it can be concluded that discipline partial work does not have a positive effect and no significant effect on employee performance.

\section{Effect of Job Satisfaction on Employee Performance.}

Based on the research that has been described statistically by using SPSS 16 it can be seen that the oversight of the work has t count equal to $(0.228<1.985)$ with significance t table $(0.820<0.05)$, then Ho is rejected and Ha accepted so that it can 
be concluded that satisfaction partial work does not have a positive effect and no significant effect on employee performance.

\section{CONCLUSIONS AND RECOMMENDATIONS}

\section{Conclusion}

1. Origin country individual employees and significant positive effect on employee performance, with a value of 3,112 and 0,002 significant value. With significantly limit $<0.05$, then Ho is rejected Ha accepted.

2. Labor discipline individually no relation to the performance of employees. With t for 0864 and the significant value was 0.390 . With significantly limit $<0.05$, then Ho is accepted Ha rejected.

3. Individual job satisfaction does not affect the performance of employees. With t count equal to 0.228 and 0.820 significant value. With significantly limit $<0.05$, then Ho is accepted Ha rejected. From the results of an analysis that adjusted R2 of 0.090 , this means that $9.0 \%$ of dependent variables influenced by independent variables consisting of variable employee national origin, work discipline, job satisfaction.

4. Country of origin of employees, work discipline, job satisfaction simultaneously (together) effect on employee performance McConnell Dowell Company Services Batam. Based on the results of the regression test is known that the normally distributed variables.

\section{RECOMMENDATIONS}

This study has been designed well, but the results of this research still has its limitations, therefore, there are some suggestions that need to be put forward to improve further research, among others:

1. Expected to researchers who will come back to proving this variable in the same case by adding another variable that has not been tested in this study.

2. This study only covers employees who work at. McConnell Dowell Company Services Batam. It is expected that further research can add a number of 
research samples and expand the sample areas and to do research in another company so that the results can be generalized to a broader scope.

3. It is expected that in future studies may test more specific about which countries have more influence on employee performance.

4. It is expected that this study can be useful for further research and serve as a reference for the study.

\section{BIBLIOGRAPHY}

Alex S. Nitisemito (2009). INSIGHTS HUMAN RESOURCES, Jakarta: Main Library graffiti.

Judge, Lukmanul. "BRAND IMAGE ANALYSIS OF INFLUENCE ON CONSUMER DECISION ON PROSPER BATAM RB." DIMENSION

5.1 (2016).

Mangkunagara, (2013), HUMAN RESOURCES MANAGEMENT, Youth Rosdakarya, Bandung.

Nasution, Ade Parlaungan. "ANALYSIS OF EFFECT OF MARKETING MIX STAR HOTEL OCCUPANCY RATE IN BATAM. "DIMENSIONS $3.2(2016)$.

Nawawi, Hadari. (2005). FOR HUMAN RESOURCE MANAGEMENT

BUSINESS COMPETITIVE, Yogyakarta

Prawirosentono. (2007). POLICY PERFORMANCE OF EMPLOYEES. Yogyakarta: BPFE

Ridwan. (2009). METHODS \& TECHNIQUES UP A PROPOSAL PENELITIAN.Bandung

Rival, V. (2005). HUMAN RESOURCES MANAGEMENT FOR COMPANIES (3rd ed). Jakarta: Rajawali Pers.

Sugiyono. (2011). QUANTITATIVE RESEARCH METHODS QUALITATIVE AND R \& D. The 13 prints. Bandung. 